\title{
Middle Eocene calcareous nannofossils in the Jaca transect (South-central Pyrenees Eocene Basin, Aragón river valley, Huesca)
}

\author{
Alba GONZÁLEZ-LANCHAS ${ }^{*}$, Eduard REMACHA', Oriol OMS ${ }^{2}$, Francisco J. SIERRO ${ }^{1}$ \\ \& José-Abel FLORES ${ }^{1}$
}

${ }^{1}$ Departamento de Geología, Facultad de Ciencias. Universidad de Salamanca, 37008 Salamanca, Spain; lanchas@usal.es, sierro@usal.es, flores@usal.es.

${ }^{2}$ Departament de Geologia, Universitat Autònoma de Barcelona, 08193 Bellaterra (Barcelona), Spain; eduard.remacha@uab.cat, joseporiol.oms@uab.cat.

*Corresponding author

González-Lanchas, A., Remacha, E., Oms, O., Sierro, F.J. \& Flores, J.A. 2019. Middle Eocene calcareous nannofossils in the Jaca transect (South-central Pyrenees Eocene Basin, Aragón river valley, Huesca). [Nanofósiles calcáreos del Eoceno medio en el transecto de Jaca (Cuenca eocena Surpirenaica Central, Valle del Río Aragón, Huesca)]. Spanish Journal of Palaeontology, 34 (2), 229-240.

Manuscript received 20 December 2017
Manuscript accepted 10 June 2019

\section{ABSTRACT}

The calcareous nanoplankton is studied from the base of the turbidite systems of the Upper Hecho Group (Jaca Basin, middle Eocene of the South-central Pyrenean Basin) up to the Gracionepel instabilities, within the Larrés slope Marls. This new chronostratigraphic contribution is of crucial importance for the improvement of the detailed temporal and spatial correlation framework of the genetically related depositional systems at basin scale.

The calcareous nanofossil assemblage is largely dominated by Coccolithus pelagicus (Wallich, 1877) Schiller, 1930, C. formous (Kamptner, 1963) Wise, 1973 as well as different species of Reticulofenestra Hay et al., 1966, accompanied by occasional specimens of several species of Sphenolithus Deflandre in Grassé, 1952 and Chiasmolithus Hay et al., 1966. The results obtained, based on the detailed biostratigraphic study of a composite succession 2,500 m thick, allow us to characterize the main biohorizons of the middle Eocene on the basis of global biostratigraphic standards. The studied succession was deposited during the CNE11-CNE15 or NP15- https://doi 10.7203/sjp.34.2.16096

(C) Sociedad Española de Paleontología ISSN 2255-0550 
NP16 biozones, within a time span of $~ 3.45$ Myr, between 43.96 and $40.51 \mathrm{Ma}$ (Lutetian/Bartonian). This age range is compatible with the existing scheme for the South-central Pyrenean Basin.

The Upper Hecho Group, between the Roncal-Fiscal megaturbidite (MT-5) and the instability facies of Gracionepel, starts in the uppermost part of Zone NP15 continues into Zone NP16.

The proposed biozonation provides new data for a correlation between stratigraphic events of other regional sections and facilitates the understanding of the lateral and temporal evolution of the studied systems, as well as the improvement of the general palaeogeographic framework of the basin.

Keywords: Calcareous nannofossils, middle Eocene, biostratigraphy, Jaca transect, Pyrenees (Spain). sucesión tuvo lugar durante las biozonas CNE11-CNE15 o NP15-NP16, con una representación estratigráfica que abarca un rango temporal de $\sim 3,45 \mathrm{Myr}$ comprendido entre los 43,96 y 40,51 Ma (Luteciense/Bartoniense). Este modelo de edad completa el existente para la Cuenca Surpirenaica Central.

La propuesta de biozonación proporciona nuevos datos para una correlación más precisa entre eventos estratigráficos de otras secciones regionales, y facilita la comprensión de la evolución lateral y temporal de los sistemas estudiados, así como la mejora del marco paleogeográfico general de la cuenca.

El Grupo Hecho superior, entre la megaturbidita de Roncal-Fiscal (MT-5) y las facies de inestabilidades de Gracionepel, se inicia en la parte terminal de la zona NP15 y se extiende dentro de la NP16.

Palabras clave: Nanofósiles calcáreos, Eoceno medio, bioestratigrafía, transecto de Jaca, Pirineos (España).

\section{INTRODUCTION}

The Hecho Group (defined by Mutti et al., 1972) is a worldwide reference model for deep-marine clastic sedimentation. Biostratigraphically, our research places the Upper Hecho Group in the depositional systems of the Jaca Basin, outcropping along the Aragón river valley (Fig. 1). The studied transect (Fig. 2) is characterised by the replacement up-section of basin floor turbidites by the slope-fan system of the lower Larrés Marls. In the study area, the lack of accurate age dating hampers the correlation of stratigraphic units between the proximal Aínsa and the Jaca Basin systems, as physical correlation is interrupted by erosion in the hinge zone of the Boltaña anticline and internal splitting by the Oturia thrust.

The available chronological data from the Hecho Group is rather limited, restricted to only a few general publications. The upper part of the group has been biostratigraphically studied in the Roncal Valley and partially located as late Lutetian (NP15 zone) by Labaume et al. (1985). Canudo \& Molina (1988) locate the Upper Hecho Group and the younger deltaic succession of the eastern Jaca Basin to between late Lutetian and early Priabonian, i.e. from P.12 to the lower P.16 zones. Oms et al. (2003) carried-out a palaeomagnetic study in the Upper Hecho Group with samples obtained along the Aragón river valley. As a result, the Upper Hecho Group turbidite systems in the Aragón valley were deposited during the time span ranging from the upper $\mathrm{C} 20 \mathrm{r}$ to the mid $\mathrm{C} 18 \mathrm{r}$ (middle Lutetian to early Bartonian times; Fig. 2).

Previous regional correlations in the Jaca Basin (Labaume et al., 1985; Remacha \& Fernández, 2003) are challenged by Oms et al. (2003) and also by magnetostratigraphic and calcareous nannofossil studies from the Aínsa Basin by Mochales et al. (2012) and Scotchman et al. (2015), respectively. Our study provides new data with the aim of resolving the controversial dating of the Jaca Basin and clarifying the general chronostratigraphic framework at basin scale.

\section{GEOLOGICAL SETTING AND STRATIGRAPHY}

The outcrop belt of the Paleogene Jaca Basin (Southcentral Pyrenees foreland basin system), forms an ESEWNW elongated asymmetrical syncline developed west of the Boltaña anticline (Fig. 1). Its thicker northern limb consists of forward breaking thrust systems involving cover rocks (Mesozoic to upper Eocene), overlying a basementinvolved duplex mostly comprising Paleozoic rocks (Cámara \& Klimowith, 1985; Labaume et al., 1985, 2016; Teixell, 1990, 1996; Cámara \& Flinch, 2017) (Fig. 1). In the cover systems and overlying lower Eocene carbonates, the Hecho Group turbidites form a thick deep-marine clastic succession reaching up to $4,500 \mathrm{~m}$ in thickness. On the southern, passive margin of the basin, this group wedges-out by lateral onlap and horizontal facies change into the Burgui Marls Formation (Cámara \& Klimowith, 1985). These marls are also the distal equivalents of the shallow-marine carbonates of the Boltaña and Guara formations (Soler-Sampere \& Puigdefàbregas, 1970; Puigdefäbregas, 1975). To the east of the Boltaña anticline, the depositinally equivalent systems of the Jaca Basin are found in the Aínsa Basin. This last basin contains most of the architectural elements such as submarine canyons, turbidite channels and slope-fan systems. The general 


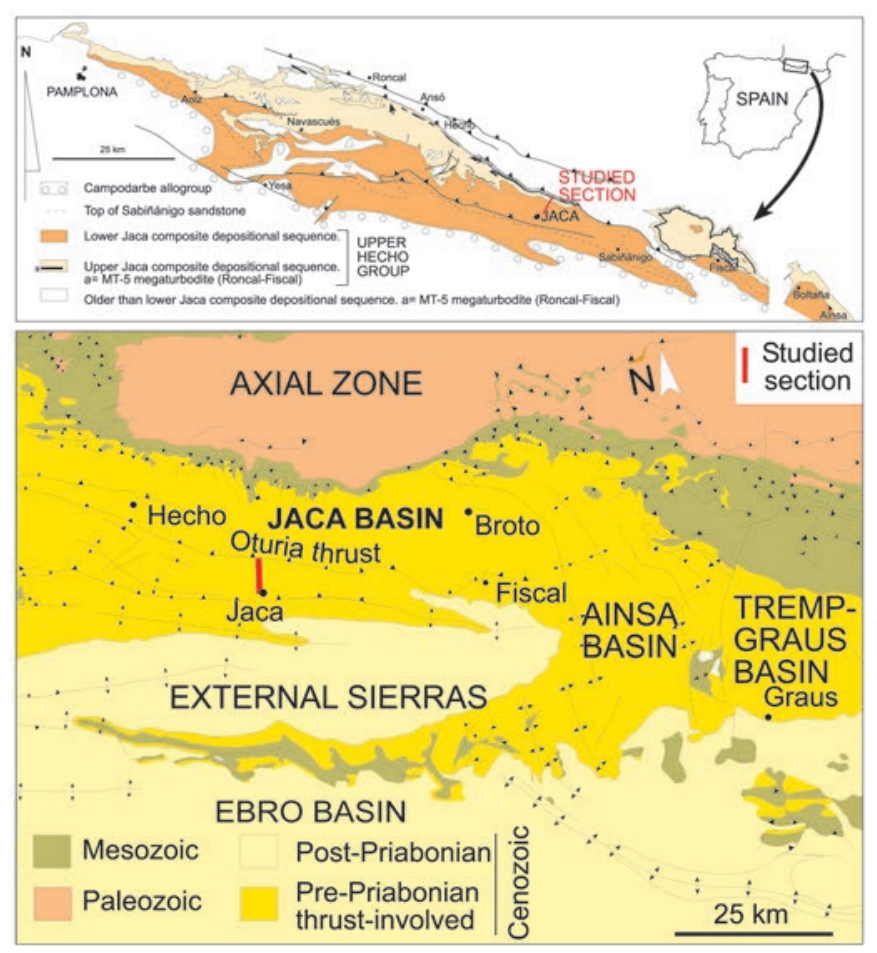

Figure 1. Geological setting of the studied section. Top: location on a sketch map of the Upper Hecho Group. Bottom: location in the central part of the South-central Pyrenees.

E-W-continuum of turbidite elements in the Jaca Basin comprises channel-lobe transition, sheet-like lobes and finally basin plain. Exceptions to the general distribution of architectural elements within the Hecho Group have been found in the uppermost part of the section in the Jaca Basin (Remacha et al., 1987, 1995; Remacha \& Picart, 1991), culminating in the northly-derived Rapitán turbidite system, the last turbidite system in the basin.

The studied section is ca. $2,500 \mathrm{~m}$ thick and is located north of Jaca, along the Aragón river valley. It is summarised in graphic form in Figure 2, together with the associated bio- and chronostratigraphic framework. The following section is a simplified review of the key depositional elements comprising the study transect.

At the base of the section and the starting point of the lower Jaca turbidite system (abbreviated hereinafter as LJSt), the Roncal-Fiscal megaturbidite (Mt-5) is found, bounded to the north by the Oturia thrust. The top of the section is marked by the Gracionepel instabilities (Gracionepel facies of Puigdefàbregas, 1975), within the Larrés Marls. These marls are interpreted as a slope fan, developing above the Rapitán turbidite channel of the upper Jaca turbidite system (abbreviated hereinafter as UJSt), and are genetically related to the Sabiñanigo Sandstone delta complex sealing the Eocene deep-marine clastic sediments in the South-central Pyrenees.
The basal ca. 1,100 $\mathrm{m}$ of the composite section (LJSt, see Fig. 2) contains the unit formerly known as the Banastón turbidites, represented in the Aragón valley by sheet-like lobe elements (Remacha \& Fernández, 2003; Remacha et al., 2005). LJSt contains three megaturbidites: Mt-5 (Roncal Fiscal), Mt-6 and Mt-7. In the Aragón section, the LJSt is sharply overlain by thick-bedded and very sand-rich facies forming the Torrijos Bridge lobes, comprising channel-lobe transition elements overlain by the Mt- 8 megaturbidite.

The stratigraphic succession subsequently comprises a ca. $70 \mathrm{~m}$ thin-bedded package containing several distinctive, medium-scale cross-bedded sandstone beds. The following $50 \mathrm{~m}$ occurs in restricted outcrops, which are also thin-bedded with local sheet-like sandy intervals. The ensuing Charlé lobes are ca. $60 \mathrm{~m}$ thick and locally derived from the north. These lobes are relatively thickbedded, sand-rich and sheet-like. The Charlé lobes are themselves overlain by $300 \mathrm{~m}$ of muddier, sheet-like lobes characterised by fewer thick beds and a net-to-gross of around $50 \%$. The top of this unit is defined by a remarkable submarine erosional feature linked to the development of the Rapitán channel (Remacha et al., 1987, 1995), the last turbidite system of the Hecho Group. In the studied section, the channel fill contains minor, thick-bedded, lenticular channel sand bodies separated by muddy debrites.

The upper part of the Rapitán channel evolves upward to the thin-bedded, lower Larrés Marls, which have a thickness of ca. $200 \mathrm{~m}$. The latter are capped by the instabilities with abundant dolomite concretions of the Gracionepel facies, forming the slope and base-of-slope environments of the lower Sabiñánigo deltas (Remacha \& Picart, 1991)

The Hecho Group has been placed within a framework of tectonosedimentary units (TSUs) by Remacha \& Fernández (2003). These units are considered as secondorder basinal divisions, each containing a number of third-order composite depositional sequences. Within the second-order framework, the upper Hecho Group comprises TSU-4 and TSU-5 (Remacha et al., 1987; Remacha \& Picart, 1991; Remacha \& Fernández, 2003). The turbidites of TSU-4 and TSU-5 belong, respectively, to LJSt and UJSt.

A distinctive feature of the Upper Hecho Group in the Jaca Basin is the occurrence of the four, previously described, thick carbonate megaturbidites (Fig. 2). These megaturbidites, with a significant lateral extension, may be regarded as extremely useful time-line marker-beds. They provide first-order physical correlation and segregation of strictly time-equivalent stratal packages extending for significant distances within the Upper Hecho Group of the Jaca Basin (Labaume et al., 1985; Remacha \& Fernández, 2003; Remacha et al., 2005). 


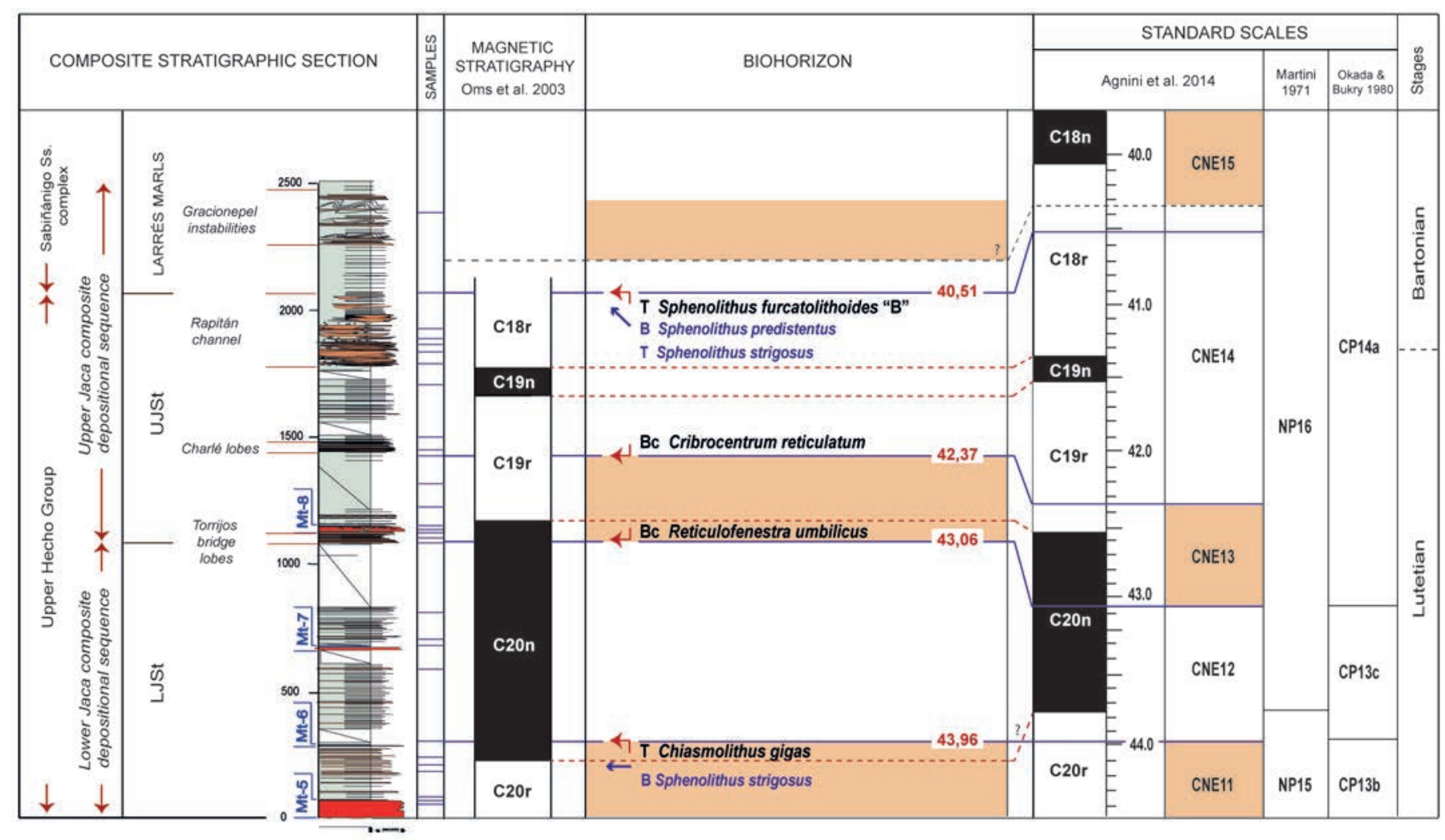

LJSt - Lower Jaca Sequence turbidite (formerly Banastón turbidites)

UJSt - Upper Jaca Sequence turbidites

Mt - Megaturbidite

Figure 2. Integrated magneto-biostratigraphic data fom the Aragón valley section. Lithostratigraphic section to the left contains: LJSt = Lower Jaca Sequence Turbidites (formerly Banastón turbidites); UJSt = Upper Jaca Sequence Turbidites; Mt = Megaturbidites. Calcareous nannofossil sampling levels and magnetostratigraphic record by Oms et al. (2003). Center: biostratigraphic results, with red arrows indicating significant bioevents (Agnini et al., 2014) and blue arrows indicating other biomarkers (Perch-Nielsen, 1985; Bown \& Dunkey Jones, 2006; Martini, 1971; Okada \& Bukry, 1980). Right: Standard biozonation and magnetostratigraphic assignation for middle Eocene according to Agnini et al. (2014). Correspondence with standard scales of Martini (1971) and Okada \& Bukry (1980). Eocene stages.

\section{METHODS}

A total of 29 samples were prepared following the Flores \& Sierro (1997) settling technique, allowing for the generation of homogeneous and comparable data. For observation, a Nikon eclipse $80 \mathrm{i}$ polarized microscope was used at 1,000x magnification. The abundance of calcareous nannofossils was analyzed by systematic counting of the total content of non-reworked nannofossils in a pre-established area of 50 fields per sample (equivalent to $1 \mathrm{~mm}^{2}$ ). The quantitative pattern of selected biomarker taxa is expressed in percentages calculated in relation to the total number of nannofossils in each sample (Fig. 3).

Calcareous nannofossils were identified using the taxonomic concepts of Perch-Nielsen (1985), Bown (1998), Young et al. (1997, 2003, 2017). A total of 74 different species have been identified (Appendixes I and II).

\section{CALCAREOUS NANNOFOSSIL ASSEMBLAGE}

The calcareous nannofossil content in the studied samples is generally rich, although we have observed variations in nannofossil concentrations between sedimentary units. Despite this, a high diversity of species is constant throughout the Jaca section.

The preservation of coccoliths was good to moderate, with ocassionnal low dissolution and partial breaking of large specimens, such as Discoaster Tan, 1927 and Reticulofenestra spp. For Chiasmolithus spp. only complete specimens with the central cross were identified.

The assemblages are dominated by Reticulofenestra spp., Dictyococcites Black, 1967, Cribrocentrum reticulatum (Perch-Nielsen, 1985), Coccolithus pelagicus, and Coccolithus formosus. For Reticulofenestra umbilicus (Levin, 1965) Martini \& Ritzkowski, 1968 we have only considered specimens larger than $14 \mu \mathrm{m}$ (Backman, 1986; 


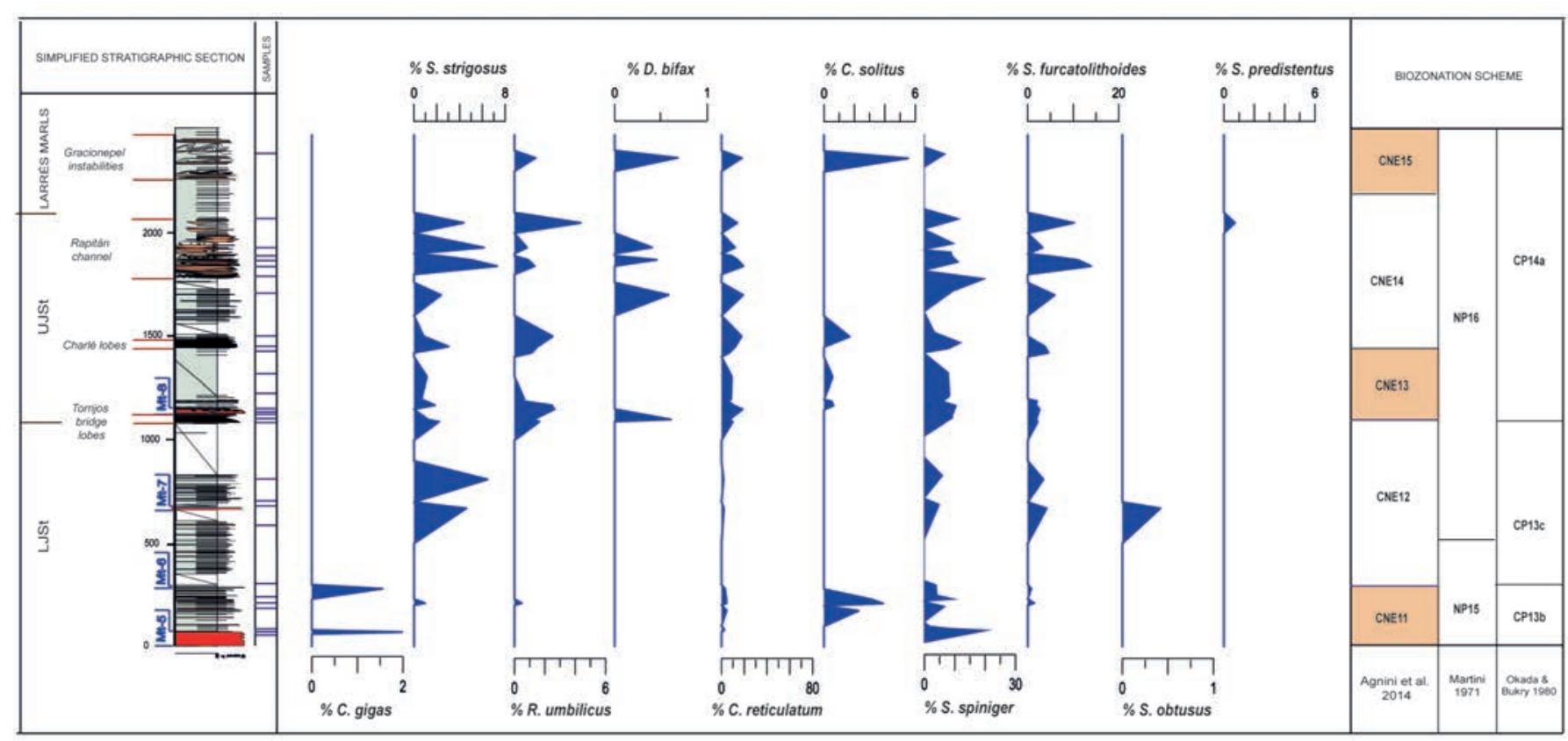

Figure 3. Percentaje of abundance of biostratigraphically significant calcareous nannofossils and its position in relation to the simplified composite stratigraphic section (see more details in Fig. 2).

Backman \& Hermelin, 1986; Wei \& Wise, 1989; Fornaciari et al., 2010; Norris et al., 2014).

Sphenolithus moriformis (Brönnimann \& Stradner, 1960) Bramlette \& Wilcoxon, 1967, Sphenolithus spiniger Bukry, 1971, Sphenolithus furcatolithoides Locker, 1967, Sphenolithus strigosus Bown \& Dunkley Jones, 2006, and Sphenolithus predistentus Bramlette \& Wilcoxon, 1967 are also abundant. Pemma Klumpp, 1953, Zygrhablithus bijugatus (Deflandre in Deflandre and Fert, 1954) Deflandre, 1959, Blackites Hay \& Towe, 1962, and Lanternithus Stradner, 1962 have a significant level of abundance. Discoaster spp. and Chiasmolithus spp., Helicosphaera Kamptner, 1954 and Pontosphaera Lohmann, 1902 are occasionally recorded. Cretaceous reworked nannofossils are consistently present but in low abundance.

Appendixes I and II show a summary of the identified calcareous nannofossil taxa.

\section{BIOSTRATIGRAPHY}

For this study we used the calcareous nannofossil biozonation and calibrated bioevents of Agnini et al. (2014), following the nomenclature of B (Base), Bc (Base common), T (Top) and Tc (Top common) for the lowest occurrence, first common record, last occurrence and highest common record in the studied section, respectively.

Some bioevents of the standard zonation of Martini (1971) and Okada \& Buckry (1980) have also been identified. In addition, a few additional biomarkers described by Perch-Nielsen (1985), Bown \& Dunkey Jones (2006), and Fornaciari et al. (2010) have been identified, supporting the correlation between the standard schemes.

Table 1 is a summary of the identified chronographically calibrated events.

\section{RESULTS AND DISCUSSION}

Our results from the Upper Hecho Group, in the Aragón river valley are derived from the same section and outcrops studied for magnetostratigraphic purposes by Oms et al. (2003); i.e., in the succession formed by LJSt, containing Mt-5, Mt-6 and Mt-7 megaturbidites, overlain by UJSt (between the Torrijos Bridge lobes to the top of the Rapitán channel system). Therefore, the magnetostratigraphic units, defined by Oms et al. (2003) in the Aragón valley, can be combined with the calcareous nannoplankton zones proposed here.

The presence of Sphenolithus cuniculus Bown, 2005 together with Chiasmolithus gigas (Bramlette \& Sullivan, 1961) Radomski, 1968, from the lowest part of LJSt, permits identification of zone CNE11 (Sphenolithus cuniculus/Chiasmolithus gigas Concurrent Range Zone), included in the Lutetian. Agnini et al. (2014) dated the Bc of S. cuniculus at $44.64 \mathrm{Ma}$. Consequently, the age of the materials studied here is younger (Fig. 2).

Zone CNE11 corresponds to the upper part of zone NP15 (Martini, 1971) and to upper part of Subzone CP13b (Okada \& Bukry, 1980), also identified in the Jaca section 
Table 1. List of calcareous nannofossil events: height $(\mathrm{m})$, event, species, age $(\mathrm{Ma})$ and magnetic chron. $\mathrm{B}=$ base; $\mathrm{Bc}=\mathrm{base}$ common; $\mathrm{T}=$ Top; $\mathrm{Tc}=$ Top common. Additional information (reference work and time scale reference) is also provided.

\begin{tabular}{lllll}
\hline High $(\mathrm{m})$ & Event & Species & Ref. & Age (Ma) \\
\hline 2050 & B & Sphenolithus predistentus & Bown \& Dunkley Jones (2006) & C18r \\
2050 & B & Sphenolithus furcatolithoides (B) & Agnini et al. (2014) & 40.51 \\
2050 & T & Sphenolithus strigosus & Bown \& Dunkley Jones (2006) & 42.37 \\
1450 & Bc & Cribrocentrum reticulatum & Agnini et al. (2014) & C19r \\
1090 & Bc & Reticulofenestra umbilicus & Agnini et al. (2014) & C20n \\
280 & T & Chiasmolithus gigas & Agnini et al. (2014) & C20r \\
210 & B & Sphenolithus strigosus & Bown \& Dunkley Jones (2006)
\end{tabular}

based on the presence of Blackites gladius (Locker, 1967) Varol 1989, Blackites inversus (Bukry \& Bramlette, 1969) Bown \& Newsam, 2017, Lanternithus arcanus Bown, 2005, Sphenolithus spiniger, Sphenolithus furcatolithoides, and Nannotetrina Achuthan \& Stradner, 1969 (Fig. 2).

The $\mathrm{T}$ of $C$. gigas marks the base of zone CNE12 (Nannotetrina spp. PRZ), dated at $43.96 \mathrm{Ma}$ in chron C20r (Agnini et al., 2014). This biohorizon is identified above the Mt-6 of the LJSt (Fig. 2).

The T of B. gladius marks the zone NP15-NP16 boundary (Martini, 1971), traditionally considered as correlative with the T of C. gigas (Okada \& Buckry, 1980; Perch-Nielsen, 1985; Martini \& Müller, 1986). In the Jaca section, $B$. gladius is still observed, although very scarce, within the LJSt unit, up to Mt-6 (CNE12). We cannot discard the possibility of some reworking or a certain degree of diachronism for this event, located by some authors within zone NP16 (Wei \& Wise, 1989; Berggren \& Aubry, 1984) and also at zone NP17 (Berggren \& Aubry, 1984). Despite ambiguity surrounding the establishment of the zone NP15-NP16 boundary, we have elected here to follow the correlation of Agnini et al. (2014), which would place it within zone CNE12.

A high abundance of $S$. strigosus has also been observed within zone CNE12 in the Jaca section (Fig. 3). The B of this species is placed within zone NP16 (Bown $\&$ Dunkley Jones, 2006), supporting the correspondence of zones CNE12 and NP16 in this part of the section, above Mt-6 (Fig. 2). The observation of a few specimens in zone CNE11, corresponding to zone NP15 (Lutetian), is also described by Lupi \& Wise (2006) and Fioroni et al. (2015).

The $\mathrm{Bc}$ of $R$. umbilicus $(\geq 14 \mu \mathrm{m})$ marks the base of zone CNE13 (Reticulofenestra umbilicus Base Zone) dated at 43.06 Ma in chron C20n (Agnini et al., 2014). This biohorizon was identified in the Torrijos Bridge lobes, beneath Mt-8 of the lower UJSt unit (Fig. 2).
On the basis of the bioevents T of $C$. gigas and $\mathrm{Bc}$ of $R$. umbilicus, the LJSt unit should be chronostratigraphically defined as ranging from $\mathrm{C} 20 \mathrm{r}$ to $\mathrm{C} 20 \mathrm{n}$ (Fig. 2), which is in agreement with the proposal of Oms et al. (2003). In detail, the $\mathrm{C} 20 \mathrm{r}-\mathrm{C} 20 \mathrm{n}$ polarity reversal, in this paper, is defined at stratigraphic levels below our placement of the $\mathrm{T}$ of $C$. gigas (Fig. 2). We should accordingly consider a possible diachronism associated with this event. In addition, we cannot discard reworking. Although the number of samples analysed for magnetostratigraphy, across this interval were indeed interpreted as a polarity reversal, a significant scattering of the declination and inclination values was also observed, so that, some slight modification of the exact position of the reversal event cannot be completely ruled out. A high-resolution revision is required here of both biostratigraphy and magnetostratigraphy in order to calibrate age assignations.

The $\mathrm{Bc}$ of $C$. reticulatum is used to define the base of zone CNE14 (C. reticulatum BZ) included in the Lutetian and dated at 42.37 Ma in chron C19r (Agnini et al., 2014). This event was identified at the Charlé lobes stratigraphic level of UJSt (Fig. 2). Agnini et al. (2014) documented, nonetheless, a sporadic occurrence in zone CNE13. In the LJSt unit, specimens of $C$. reticulatum (with unclear central net) were sporadically observed.

The boundary between zones CNE14-CNE15 (D. bisectus-S. obtusus CRZ) is defined by the B of Dictyococcites bisectus (Hay et al., 1966) Bukry \& Percival, 1971 in the Bartonian and dated at $40.34 \mathrm{Ma}$ in chron C18r (Agnini et al., 2014). The scarce record of these specimens precludes a precise placement of the event, which, however, is identified within the LJSt unit. Other authors have considered this event as diachronic (Mita, 2001; Larrasoaña et al., 2008).

The T of S. furcatolithoides morphotype B (Agnini et al., 2014) is constrained to the upper part of zone CNE14, 
included in the Bartonian and dated at 40.51 Ma in chron C18r (Agnini et al., 2014). This biohorizon was identified in the Rapitan channel system, in the upper part of UJSt unit (Fig. 2).

The UJSt unit is bounded by the $\mathrm{Bc}$ of $R$. umbilicus and the $\mathrm{T}$ of $S$. furcatolithoides (B) corresponding respectively to $\mathrm{C} 20 \mathrm{n}$ and $\mathrm{C} 18 \mathrm{r}$ (Fig. 2). This identification in the Jaca section is consistent with chron assignations by Oms et al. (2003), who defines the same polarity pattern for this part of the section. The intermediate location of C19r, according to Oms et al. (2003), is here also supported by the identification of $\mathrm{Bc}$ of C. reticulatum (Fig. 2).

The B of S. predistentus (Perch-Nielsen, 1985; Fornaciari et al., 2010; Toffanin et al., 2013) has been correlated by Agnini et al. (2014) with the lower part of zone CNE15, in the Bartonian. In the Jaca section, the T of S. furcatolithoides morphotype B was observed at the same stratigraphic level (Fig. 2). We used these two events to approximate the location of the CNE14-CNE15 boundary in the Rapitan channel system (Fig. 2).

The $\mathrm{T}$ of $C$. solitus has a range, which extends throughout the middle part of zone CNE15 (Agnini et al., 2014), at the bottom of zone NP17 (Martini, 1971) and CP14b (Okada \& Bukry, 1980). A scarce record of these specimens has been observed until the Gracionepel instabilities, in agreement with the base of zone CNE15 in the Bartonian (Fig. 2).

The B of Sphenolithus obtusus Bukry, 1971 and the Tc of $S$. spiniger (Fornaciari et al., 2010) are correlated with the upper part of zone CNE15 (Agini et al., 2014). The abundance of $S$. spiniger, up to the top of the section is far from the prominent decrease described in Fornaciari et al. (2010) before the Tc (Fig. 3). The B of S. obtusus was dated at $39.64 \mathrm{Ma}$ in chron C18n.2n (Fornaciari et al., 2010). The absence of this taxon in the samples permits us to interprete this section as older than this date, in agreement with Oms et al. (2003) (Fig. 2).

The biostratigraphic results presented here validate the magnetostratigraphic data and correlation by Oms et al. (2003), reinforcing the methods of this paper in the sense that it is a rare example of magnetostratigraphic techniques applied to expanded deep-marine clastic systems.

The general correlation between sedimentary units of the Aínsa and Jaca Basins should be reconsidered, comparing our results with the proposal of Mochales et al. (2012) and Scotchman et al. (2015). First, the timing of the LJSt would correspond with the Guaso turbidite systems of the Aínsa Basin. Second, the overlying lowermost part of the UJSt would be the time equivalent of the Sobrarbe delta. Finally, the last turbidite system of the Hecho Group (Rapitán channel, established in the Jaca Basin) would be the deep-marine time equivalent of the continental sediments of the lower Escanilla formation in the Aínsa Basin. Although additional work is required, the above correlation should be taken as a guideline for any revised palaeogeographic reconstruction involving the Aínsa and Jaca Basins.

\section{CONCLUSIONS}

Four age-calibated calcareous nannofossil bioevents have been identified in the Jaca transect, establishing a biostratigraphic framework for the sedimentary units of the Upper Hecho Group and Larrés Marls. These results reinforce the magnetostratigraphic scheme and correlation established by Oms et al. (2003).

Sedimentation took place during the middle Eocene, including part of Lutetian and Bartonian stages, during biozones CNE11-CNE15 or NP15-NP16, covering a time-interval of at least $\sim 3.45 \mathrm{Myr}$ between $43.96 \mathrm{Ma}$ (T of $C$. gigas) and $40.51 \mathrm{Ma}$ ( $\mathrm{T}$ of $S$. furcatolithoides morphotype B).

The correlation between the Aínsa and Jaca Basins should be revisited when integrating data by Mochales et al. (2012) and Scothchman et al. (2015). As an outline framework, the Upper Hecho Group, in the Jaca Basin, should correlate with the time span between the Guaso turbidite systems and the lower part of the already continental Escanilla Formation, with a slight overlap of the lower UJSt with the Sobrarbe Delta Formation.

\section{AKNOWLEDGEMENTS}

This work has been supported by the SEPAI-2016-07311 grant of the research aid program for young researchers awarded by the Spanish Society of Palaeontology (SEP) to Alba González-Lanchas for the development of the project "Nanoplancton calcáreo del Eoceno medio y superior en el transecto de Jaca (Cuenca Eocena Surpirenaica Central)" and by the program PGC2018-101575-B-I00 Spanish Ministry of Science, Innovation and Universities. Earlier version of this work benefitted from revision and comments by two anonymous rewiewers and those of Dra. Adele Garzarella. We are endebted to Dr. Neil McDougall for the English revision of the text.

\section{REFERENCES}

Achuthan, M.V. \& Stradner, H. 1969. Calcareous nannoplankton from the Wemmelian stratotype. In: Proceedings of the First International Conference on Planktonic Microfossils (eds. Brönnimann, P. \& Renz, H.H.). 1 Brill, Leiden, Geneva, 1-13. 
Agnini, C., Fornaciari, E., Raffi, I., Catanzariti, R., Pälike, H., Backman, J. \& Rio, D. 2014. Biozonation and biochronology of Paleogene calcareous nannofossils from low and middle latitudes. Newsletters on Stratigraphy, 47, 131-181; doi: 10.1127/0078-0421/2014/0042.

Backman, J. 1986. Late Paleocene to middle Eocene calcareous nannofossil biochronology from the Shatsky Rise, Walvis Ridge and Italy. Palaeogeography, Palaeoclimatology, Palaeoecology, 57, 43-59; doi: 10.1016/0031-0182(86)90005-2.

Backman, J. \& Hermelin, J.O.R. 1986. Morphometry of the Eocene nannofossil Reticulofenestra umbilicus lineage and its biochronological consequences. Palaeogeography, Palaeoclimatology, Palaeoecology, 57, 103-116; doi: 10.1016/0031-0182(86)90009-X.

Berggren, W.A. \& Aubry, M.P. 1984. Rb-Sr glauconite isochron of the Eocene Castle Hayne Limestone, North Carolina: Further discussion. Geological Society of America Bulletin, 95, 364-370; doi: 10.1130/0016 7606(1984)95<364:RGIOTE>2.0.CO;2.

Bown, P. 1998. Calcareous Nannofossil Biostratigraphy. Chapman and Hall, Kluwer Academic, London. 315 pp.

Bown, P.R. 2005. Palaeogene calcareous nannofossils from the Kilwa and Lindi areas of coastal Tanzania (Tanzania Drilling Project Sites 1 to 10, 2003-4). Journal of Nannoplankton Research, 27, 21-95.

Bown, P.R. \& Dunkley Jones, T. 2006. New Paleogene calcareous nannofossil taxa from coastal Tanzania: Tanzania Drilling Project Sites 11 to 14. Journal of Nannoplankton Research, 28, 17-34.

Bown, P.R. \& Dunkley Jones, T. 2012. Calcareous nannofossils from the Paleogene equatorial Pacific (IODP Expedition 320 Sites U1331-1334). Journal of Nannoplankton Research, 32, 3-51.

Bown, P.R. \& Newsam, C. 2017. Calcareous nannofossils from the Eocene North Atlantic Ocean (IODP Expedition 342 Sites U1403-1411). Journal of Nannoplankton Research, 37, 25-60.

Black, M. 1967. New names for some coccolith taxa. Geological Society of London, 1640, 139-145.

Bramlette, M.N. \& Sullivan, F.R. 1961. Coccolithophorids and related nannoplankton of the Early Tertiary in California. Micropaleontology, 7, 129-188.

Bramlette, M.N. \& Wilcoxon, J.A. 1967. Middle Tertiary calcareous nannoplankton of the Cipero section, Trinidad, W.I. Tulane Studies in Geology and Paleontology, 5, 93-131.

Brönnimann, P. \& Stradner, H. 1960. Die Foraminiferen-und Dicoasteridenzonen von Kuba und ihre interkontinentale korrelation. Erdoel-Z., 76, 364-9.

Bukry, D. 1971. Cenozoic calcareous nannofossils from the Pacific Ocean. San Diego Society of Natural History Transactions, 16, 303-327.

Bukry, D. \& Bramlette, M.N. 1969. Some new and stratigraphically useful calcareous nannofossils of the Cenozoic. Tulane Studies in Geology, 7, 131-142.

Bukry, D. \& Percival, S.F., Jr. 1971. New Tertiary calcareous nannofossils. Tulane Studies in Geology and Paleontology, 8, 123-146.
Cámara, P. \& Flinch, J.F. 2017. The Southern Pyrenees: A salt-based fold-and-thrust belt. In: Permo-Triassic Salt Provinces of Europe, North Africa and the Atlantic Margins (eds. Soto, J.I., Flinch, J. \& Tari, G.). Elsevier, pp. 395-415.

Cámara, P. \& Klimowitz, J. 1985. Interpretación geodinámica de la vertiente centro-occidental surpirenaica (Cuencas de Jaca-Tremp). Estudios geológicos, 41, 391-404.

Canudo, J.I., \& Molina, E. 1988. Biocronología con foraminíferos planctónicos de la secuencia deposicional de Jaca (Pirineo aragonés): Eoceno medio y superior. Congreso Geológico de España, Comunicaciones, 1, 273-276.

Deflandre, G. 1952. Classe des Coccolithophoridés (Coccolithophoridae Lohmann, 1902). In: Traité de Zoologie. Anatomie, Systématique, Biologie v. 1, part 1, Phylogenie. Protozoaires: generalités (ed. Grasse, P.P.). Flagellés. Masson, Paris; 439-470.

Deflandre, G. 1959. Sur les nannofossiles calcaires et leur systématique. Revue de Micropaleontologie, 2, 127-152.

Deflandre, G. \& Fert, C. 1954. Observations sur les coccolithophoridés actuels et fossiles en microscopie ordinaire et électronique. Annales de Paléontologie, 40, 115-176.

Fioroni, C., Villa, G., Persico, D. \& Jovane, L. 2015. Middle Eocene-Lower Oligocene calcareous nannofossil biostratigraphy and paleoceanographic implications from Site 711 (equatorial Indian Ocean). Marine Micropaleontology, 118, 50-62; doi: 10.1016/j. marmicro.2015.06.001.

Flores, J.A. \& Sierro, F.J. 1997. Revised technique for calculation of calcareous nannofossil accumulation rates. Micropaleontology, 43, 321-324.

Fornaciari, E., Agnini, C., Catanzariti, R., Rio, D., Bolla, E.M. \& Valvasoni, E. 2010. Mid-latitude calcareous nannofossil biostratigraphy and biochronology across the middle to late Eocene transition. Stratigraphy, 7, 229.

Hay, W.W. 1977. Calcareous nannofossils. In: Oceanic Micropalaentology (ed. Ramsay, A.T. S.). Academic Press, London 1055-1200.

Hay, W.W. \& Towe, K.M. 1962. Electron microscope examination of some coccoliths from Donzacq (France). Eclogae Geologicae Helvetiae, 55, 497-517.

Hay, W.W., Mohler, H.P. \& Wade, M.E. 1966. Calcareous nannofossils from Nal'chik (northwest Caucasus). Eclogae Geologicae Helvetiae, 59, 379-399.

Jerkovic, L. 1970. Noëlaerhabdus nov. gen. type d'un nouvelle famille de Coccolithophoridés fossiles: Noëlaerhabdaceae du Miocène supérieur de Yugoslavie. Comptes Rendus Hebdomadaires des Séances de l'Académie des Sciences. Paris. Série D - Sciences Naturelles, 270, 468-470.

Kamptner, E. 1954. Untersuchungen über den Feinbau der Coccolithen. Archiv. für Protistenkunde, 100, 1-90.

Kamptner, E. 1963. Coccolithineen-Skelettreste aus Tiefseeablagerungen des Pazifischen Ozeans. Ann. Naturh. Mus. Wien, 66, 139-204.

Klumpp, B. 1953. Beitrag zur Kenntnis der Mikrofossilien des Mittleren und Oberen Eozän. Palaeontographica A, 103, 377-406. 
Labaume, P., Meresse, F., Jolivet, M., Teixell, A. \& Lahfid, A. 2016. Tectonothermal history of an exhumed thrust-sheettop basin: An example from the south Pyrenean thrust belt. Tectonics, 35, 1280-1313: doi: 10.1016/j.crte.2015.10.010.

Labaume, P., Séguret, M. \& Seyve, C. 1985. Evolution of a turbiditic foreland basin and analogy with an accretionary prism: Example of the Eocene south-Pyrenean basin. Tectonics, 4, 661-685; doi: 10.1029/TC004i007p00661.

Larrasoaña, J.C., Gonzalvo, C., Molina, E., Monechi, S., Ortiz, S., Tori, F. \& Tosquella, J. 2008. Integrated magnetobiochronology of the Early/Middle Eocene transition at Agost (Spain): implications for defining the Ypresian/Lutetian boundary stratotype. Lethaia, 41, 395415; doi: 10.1111/j.1502-3931.2008.00096.x.

Levin, H.L. 1965. Coccolithophoridae and related microfossils from the Yazoo Formation (Eocene) of Mississippi. Journal of Paleontology, 39, 265-272.

Locker, S. 1967. Neue Coccolithophoriden (Flagellata) aus dem Alttertiär Norddeutschlands. Geologie, Berlin, 16, 361-364.

Locker, S. 1968. Biostratigraphiedes des Alttertiars von Norddeutschland mit Coccolithophoriden. Monatsberichte der Deutschen Akademie der Wissenschaften zu Berlin, 10, 220-229.

Lohmann, H. 1902. Die Coccolithophoridae, eine Monographie der Coccolithen bildenden Flagellaten, zugleich ein Beitrag zur Kenntnis des Mittelmeerauftriebs. Archiv für Protistenkunde, 1, 89-165.

Lupi, C. \& Wise, S.W., Jr. 2006. Calcareous nannofossil biostratigraphic framework for middle Eocene sediments from ODP Hole 1260A, Demerara Rise. Revue de Micropaléontologie, 49, 245-253; doi: 10.1016/j. revmic.2006.10.001.

Martini, E. 1971. Standard Tertiary and Quaternary calcareous nannoplankton zonation. In: Proceedings 2nd International Conference Planktonic Microfossils Roma (ed. Farinacci, A.). Tecnoscienza, Rome 2, 739-785.

Martini, E. \& Müller, C. 1986. Current Tertiary and Quaternary calcareous nannoplankton stratigraphy and correlations. Newsletters on Stratigraphy, 16, 99-112.

Martini, E. \& Ritzkowski, S. 1968. Was ist das ,Unter-Oligozän‘? Eine analyse der Beyrich'schen und v Koenen'schen Fassung der Stufe mit Hilfe des fossilen Nannoplanktons. Nachr Akad Wiss Gottingen; II Mathematisch-Physikalische Klasse, 13, 231-250.

Mita, I. 2001. Data report: Early to late Eocene calcareous nannofossil assemblages of Sites 1051 and 1052, Blake Nose, northwestern Atlantic Ocean. Proceedings of the Ocean Drilling Program, Scientific Results B, 171, 1-28.

Mochales, T., Barnolas, A., Pueyo, E.L., Serra-Kiel, J., Casas, A.M., Samsó, J.M., Ramajo, J. \& Sanjuán, J. 2012. Chronostratigraphy of the Boltaña anticline and the Ainsa Basin (Southern Pyrenees). Geological Society of America Bulletin, 124, 1229-1250; doi:10.1130/B30418.1.

Mutti, E., Luterbacher, H.P., Ferrer, J. \& Rosell, J. 1972. Schema estratigrafico e lineamenti di facies del Paleogene marino della zona centrale sudpirenaica tra Tremp (Catalogna) e Pamplona (Navarra). Memoria della Societá Geologica de Italia, 11, 391-416.
Norris, R.D., Wilson, P.A., Blum, P. \& the Expedition 342 Scientists. 2014. Proceedings IODP, 342. College Station, TX (Integrated Ocean Drilling Program); doi: 10.2204/ iodp. proc.342.2014.

Oms, O., Dinarès-Turell, J. \& Remacha, E. 2003. Magnetic stratigraphy from deep clastic turbidites: an example from the Eocene Hecho group (southern Pyrenees). Studia Geophysica et Geodaetica, 47, 275-288; doi: 10.1023/A:1023719607521.

Okada, H. \& Bukry, D. 1980. Supplementary modification and introduction of code numbers to the low-latitude coccolith biostratigraphic zonation (Bukry, 1973; 1975). Marine Micropaleontology, 5, 321-325; doi: 10.1016/03778398(80)90016-X.

Pascher, A. 1910. Chrysomonaden aus dem Hirschberger Grossteiche. Monographien und Abhandlungen zur Internationalen Revue der gesamten Hydrobiologie und Hydrographie, 1, 66.

Perch-Nielsen, K. 1971. Elektronenmikroskopische untersuchungen an Coccolithen und verwandten Formen aus dem Eozan von Danemark. Biologiske Skrifter. Kongelige Danske Videnskabernes Selskab, 18, 1-76.

Perch-Nielsen, K. 1985. Mesozoic calcareous nannofossils. In: Plankton Stratigraphy (eds. Bolli, H.M., Saunders, J.B. \& Perch-Nielsen, K.). Cambridge University Press, Cambridge, 329-426.

Poche, F. 1913. Das System der Protozoa. Archiv für Protistenkunde, 30, 125-321.

Puigdefàbregas, C. 1975. La sedimentación molásica en la Cuenca de Jaca. Monografías del Instituto de Estudios Pirenaicos, Jaca (Spain). 104, 187 p.

Radomski, A. 1968. Calcareous nannoplankton zones in the Paleogene of the Western Polish Carpathian. Annales de la Société Géologique de Pologne, 38, 544-605.

Remacha, E. \& Fernández, L. P. 2003. High-resolution correlation patterns in the turbidite systems of the Hecho Group (South-Central Pyrenees, Spain). Marine and Petroleum Geology, 20, 711-726; doi: 10.1016/j. marpetgeo.2003.09.003

Remacha, E. \& Picart, J. 1991. El complejo turbidítico de Jaca y el delta de la arenisca de Sabiñánigo. Excursion Guide Book, 8. 1er. Congresso del Grupo Español del Terciario. Vic Universitat de Barcelona.

Remacha, E., Arbués, P. \& Carreras, M. 1987. Precisiones sobre los límites de la secuencia deposicional de Jaca. Evolución de las facies desde la base de la secuencia hasta el techo de la arenisca de Sabiñánigo. Boletín Geológico y Minero de España, 98, 40-48.

Remacha, E., Fernández, L.P. \& Maestro, E. 2005. The transition between sheet-like lobe and basin-plain turbidites in the Hecho Basin (South-Central Pyrenees, Spain). Journal of Sedimentary Research, 75, 798-819; doi: 10.2110/jsr.2005.064.

Remacha, E., Oms, O. \& Coello, J. 1995. The Rapitán turbidite channel and its related eastern levee-overbank deposits, Eocene Hecho group, south-central Pyrenees, Spain. In: Atlas of Deep Water Environments (eds, Pickering, K.T., Hiscott, R.N., Kenyon, N.H., Ricci 
Lucchi, F. \& Smith, R.D.A.). Springer Netherlands, 145149. doi: 10.1007/978-94-011-1234-5_22.

Schiller, J. 1930. Coccolithineae. Rabenhorst's KryptogamenFlora. Kryptogamen-Flora von Deutschland, Osterreich und der Schweiz. Leipzig: Akademische Verlagsgesellschaft $\mathrm{MBH}$.

Schwartz, E.H.L. 1894. Coccoliths. Annals and Magazine of Natural History, Jun-14, 341-346.

Scotchman, J.I., Bown, P., Pickering, K.T., BouDagher-Fadel, M., Bayliss, N.J. \& Robinson, S.A. 2015. A new age model for the middle Eocene deep-marine Ainsa Basin, Spanish Pyrenees. Earth-Science Reviews, 144, 10-22; doi: 10.1016/j. earscirev.2014.11.006.

Soler-Sampere, M. \& Puigdefàbregas, C. 1970. Líneas generales de la geología del Alto Aragón Occidental. Pirineros, 95, 5-19.

Stradner, H. 1962. Über neue und wenig bekannte Nannofossilien aus Kreide und Alttertiär. Sonderabdruck aus den Verhandlungen der Geologischen Bundesanstalt, 2, 363-377.

Tan, S.H.1927. Discoasteridae incertae sedis. Proceedings of the Koninklijke Nederlandse Akademie van Wetenschappen, Sect Sci, 30, 411-419.

Teixell, A. 1990. Alpine thrusts at the western termination of the Pyrenean Axial Zone. Bulletin de la Société Géologique de France, 6, 241-249.

Teixell, A. 1996. The Ansó transect of the southern Pyrenees: basement and cover thrust geometries. Journal of the Geological Society, 153, 301-310; doi: 10.1144/ gsjgs.153.2.0301.
Toffanin, F., Agnini, C., Rio, D., Acton, G., \& Westerhold, T. 2013. Middle Eocene to early Oligocene calcareous nannofossil biostratigraphy at IODP Site U1333 (equatorial Pacific). Micropaleontology, 59, 69-82.

Varol, O. 1989. Eocene calcareous nannofossils from Sile (northwest Turkey). Revista Española de Micropaleontología, 21, 273-320.

Wallich, G.C. 1877. XXXIV - Observations on the Coccosphere. Journal of Natural History, 19, 342-350.

Wei, W. \& Wise, S.W. 1989. Paleogene calcareous nannofossil magnetobiochronology: results from South Atlantic DSDP Site 516. Marine Micropaleontology, 14, 119-152; doi: 0.1016/0377-8398(89)90034-0.

Wise, S.W. 1973. Calcareous nannofossils from cores recovered during Leg 18, Deep Sea Drilling Proyect: biostratigraphy and observations on diagénesis. Initial Report, Deep Sea Drilling Project, 18, 569-615.

Young, J.R. \& Bown, P.R. 1997. Higher classification of calcareous nannofossils. Journal of Nannoplankton Research, 19, 15-20.

Young, J.R., Bergen, J.A., Bown, P.R., Burnett, J.A., Fiorentino, A., Jordan, R.W., Kleijne, A., Niel, B.E., Van Romein, A.J.T. \& Von Salis, K. 1997. Guidelines for coccolith and calcareous nannofossil terminology. Palaeontology, 40, 875-912.

Young, J.R., Bown, P.R. \& Lees, J.A. (eds.) 2017. Nannotax3 website. International Nannoplankton Association. 21 Nov. 2017. URL: http://ina.tmsoc.org/Nannotax3.

Young, J.R., Geisen, M., Cros, L., Kleijne, A., Sprengel, C., Probert, I. \& Østergaard, J. 2003. A guide to extant coccolithophore taxonomy. Journal of Nannoplankton Research, 1, 1-125. 


\section{APPENDIX I: CALCAREOUS NANNOFOSSIL SYSTEMATICS}

\section{Calcareous nannofossil biomarker genus and species}

Order ISOCHRYSIDALES Pascher, 1910.

Family Noelaerhabdaceae Jerkovic, 1970 emend. Young \& Bown, 1997.

Genus Reticulofenestra Hay, Mohler \& Wade, 1966.

Reticulofenestra umbilicus (Levin, 1965) Martini \& Ritzkowski, 1968.

(Fig. 4d)

Genus Cribrocentrum Perch-Nielsen, 1971

Cribrocentrum reticulatum (Perch-Nielsen, 1985)

(Fig. 4e)

Genus Dictyococcites (Hay, Mohler \& Wade, 1966) Bukry \& Percival, 1971.

Dictyococcites bisectus (Hay, Mohler \& Wade, 1966) Bukry \& Percival, 1971.

Order COCCOLITHALES Schwarz, 1932.

Family Coccolithaceae Poche, 1913 emend. Young \& Bown, 1997.

Genus Coccolithus Schwarz, 1894

Coccolithus gigas (Bramlette \& Sullivan, 1961) Radomski, 1968.

(Fig. 4a)

Genus Chiasmolithus Hay et al., 1966.

Chiasmolithus solitus (Bramlette \& Sullivan, 1961) Locker, 1968.

(Fig. 4f)

Order DISCOASTERALES Hay, 1977

Family Sphenolithaceae Deflandre, 1952

Genus Sphenolithus Deflandre in Grassé, 1952

Sphenolithus furcatolithoides Group sensu Bown \& Dunkley Jones, 2012

Sphenolithus furcatolithoides Locker, 1967; morphotype "B" Perch-Nielsen, 1985
Sphenolithus strigosus Bown \& Dunkley Jones, 2006

(Figs 4b, 4c)

Sphenolithus radians Group sensu Bown \& Dunkley Jones, 2012

Sphenolithus spiniger Bukry, 1971

(Figs 4g, 4h)

Sphenolithus predistentus Group sensu Bown \& Dunkley Jones, 2012

Sphenolithus predistentus Bramlette \& Wilcoxon, 1967

(Figs 4k, 4l)
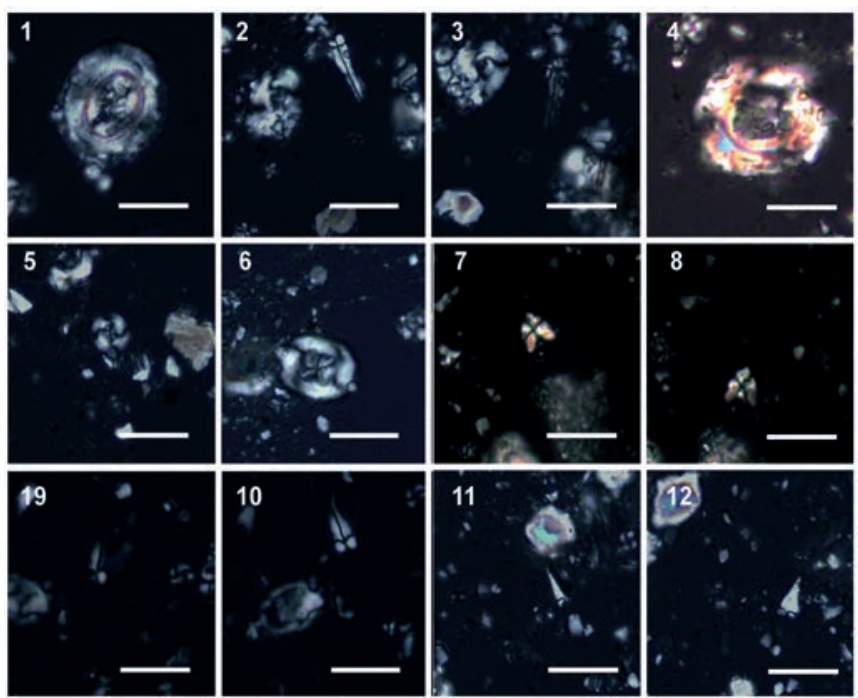

Figure 4. Microphotographs of Eocene calcareous nannofossil index species from the Jaca section. a) Chiasmolithus gigas (sample 6). b) Sphenolithus strigosus $0^{\circ}$ (sample 7). c) Sphenolithus strigosus $45^{\circ}$ (sample 11). d) Reticulofenestra umbilicus $>10 \mu \mathrm{m}$ (sample 20). e) Cribrocentrum reticulatum (sample 22). f) Chiasmolithus solitus (sample 6). g) Sphenolithus spiniger $0^{\circ}$ (sample 2). h) Sphenolithus spiniger $45^{\circ}$ (simple 2). i) Sphenolithus furcatolithoides "B" $20^{\circ}$ (sample 23). j) Sphenolithus furcatolithoides " $\mathrm{B}$ " $0^{\circ}$ (sample 23). k) Sphenolithus predistentus $0^{\circ}$ (sample 28). I) Sphenolithus predistentus $45^{\circ}$ (sample 28). Scale bars $10 \mu \mathrm{m}$.

(Figs $4 \mathrm{i}, 4 \mathrm{j}$ ) 


\author{
APPENDIX II. OTHER TAXA CITED IN Discoaster Tan, 1927 \\ TEXT \\ Helicosphaera Kamptner, 1954 \\ Lanternithus Stradner, 1962 \\ Lanternithus arcanus Bown, 2005 \\ Blackites Hay \& Towe, 1962 \\ Blackites gladius (Locker, 1967) Varol, 1989 \\ Lanternithus inversus Bown, 2005 \\ Nannotetrina Achuthan \& Stradner, 1969 \\ Blackites inversus (Bukry \& Bramlette, 1969) Bown \& \\ Pemma Klumpp, 1953 \\ Newsam, 2017 \\ Coccolithus Schwartz, 1894 \\ Coccolithus pelagicus (Wallich 1877) Schiller, 1930 \\ Coccolithus formosus (Kamptner, 1963) Wise, 1973 \\ Dictyococcites Black, 1967 \\ Dictyococcites bisectus (Hay et al., 1966) Bukry \& \\ Percival, 1971 \\ Dictyococcites scrippsae Bukry \& Percival, 1971. \\ Pontosphaera Lohmann, 1902 \\ Sphenolithus Deflandre in Grassé, 1952 \\ Sphenolithus cuniculus Bown, 2005 \\ Sphenolithus moriformis (Brönnimann \& Stradner, 1960) \\ Bramlette \& Wilcoxon, 1967 \\ Zygrhablithus Deflandre, 1959 \\ Zygrhablithus bijugatus (Deflandre in Deflandre \& Fert, \\ 1954) Deflandre, 1959
}

